\title{
How to Teach Make Up for The Beginner in ATMAISWARI
}

\author{
Asri Wibawa Sakti ${ }^{1}$, Rasi Yugafiati ${ }^{2}$, Tri Karyono ${ }^{3}$, Mally Maeliah ${ }^{4}$ \\ ${ }^{1}$ Sekolah Pasca Sarjana Universitas Pendidikan Indonesia, Bandung, Indonesia \\ ${ }^{2}$ P.B. Inggris IKIP Siliwangi Bandung, Bandung, Indonesia \\ ${ }^{3}$ FPBS UPI Bandung, Bandung, Indonesia \\ ${ }^{4}$ FPTK UPI Bandung, Bandung, Indonesia \\ ${ }^{1}$ achiewibawasakti@gmail.com; 2 tanya.rasiyugafiati@gmail.com; \\ 3 tanya.rasiyugafiati@gmail.com; 4 tanya.rasiyugafiati@gmail.com
}

\begin{abstract}
The article aims to discuss about how to teach make up for the beginner through an organized event. The researcher explains about step by step to make a great event such as AISMAWARI. The research is descriptive qualitative. The researcher describes the study briefly. The researcher posts and analizes, and explains the Figures briefly from pre-event, the main event, and the post event. The research reveals the phenomenon that collaboration is needed to make a big events. It also collaborates with a hundred of make up artists, a hundred of designers, and a hundred of models. It involves many supporters. It is held at Atrium Istana Plaza Bandung, in Pasir Kaliki Street no. 121-123. The due date is March 8th, 2019. It related to the primary education pedagogy. It is because the researcher tries to teach the beginner although it is covered by multiliteracy and multiagendas in a big events. The goal is to ask the participants or beginners to think in higher level. The researcher wants to educate the beginner not only to hear the material, but also do the action. As it is believed, practices make perfect.
\end{abstract}

Keywords: AISMAWARI, multiliteracy, think in higher level, make up artist, collaborate

\section{Introduction}

Nowadays, Multiliteracy moves to many parts in daily life. Multiliteracy is not only cover the way people read the books literally, but also how people can read and understand the phenomenon in this real life. Then, the multiliteracy tries to answer the problems which are faced by people. Then, in the next level, multiliteracy ask people to think in higher level and to solve the problem.

Related to the multiliteracy, the researcher wants to show another point of view about reading the culture. In this millenial era 4.0, some people move to the new habitual action to watch what is happening on the social media. People who do those activities are called netizen. On youtube, the are called followers. Then, then comment about what are already seen. 


\section{Related Work}

\subsubsection{Multiliteracy}

Multiliteracy concept blows up in education segmentation because people are not only write and read, but also do the specific aims such as read the society, culture, and politics as the globalization order [1]. Multiliteracy can help learners not only read but also to understand [2]. Learner should understand between one and other concept by a kind of meaningful learning by doing various activities [3]. Multiliteracy in teaching can be seen from practice situation, open learning, cricital thinking reflection, and transformative practice [4]. Multiliteracy learning proccesses are grasped multicontext, multimedia, and multiculture [5]. Moreover, multiteracy has three steps: habituation, development, and learning [5]. Multiliteration learning model helps learners to improve their higher level thinking skill [6].

\subsection{Teaching makeup}

Contextual Teaching and Learning in studying the make up supports the learners to have correlation between the knowledge and real life situation by seven steps: constructivism, questioning, inquiry, learning community, modelling, and authentic assessment [7]. Teaching skill means helping learners to be ready for working and taking opportunity [8]. The training is held to help the learners practice a lot [9]. Tutorial make up practicing has three steps: preparation, practice, and evaluation [10].

\subsection{Technology}

The developing of technology then requires the learners to have skill and knowledge [11].

\section{Design Overview}

The design overview made by researcher has several stages. At the first, the researcher explains about how to organize the commitee. The second, the researcher tells about how to gather the supporters. The third, the researcher and the commitee make advertisements. The fourth, the reseacher describes about opening the registration for the participants. The fifth, the researcher tells about how the event runs. The research is qualitative. It is described briefly.

\section{Result And Discussion}

The event of ATMAISWARI can be held by three months of preparation. The preparation is arranged to support the idea in educating the society, as the order in modern era [1]. ATMAISWARI supports the idea of multiliteracy in the society. Those are explained briefly below. 
Table 1. Teach Make Up For The Beginner in ATMAISWARI

\begin{tabular}{|c|c|c|c|}
\hline \multirow{2}{*}{ Stages } & \multicolumn{3}{|r|}{ Design Overview } \\
\hline & Strategies & Month & responds after doing the strategies \\
\hline \multirow{14}{*}{ preparation } & \multirow{2}{*}{$\begin{array}{l}\text { organize the } \\
\text { commitee }\end{array}$} & & 1. Discussion with the community of MUA. \\
\hline & & 1 & 2. Agreement to make an event. \\
\hline & & & 1. the commitee keep in touch with several links, \\
\hline & gather the supporters & 2 & vendors, supporters from previous events/ \\
\hline & \multirow{4}{*}{ make advertisements } & \multirow{4}{*}{2} & 1. event proposal \\
\hline & & & 2. flyer \\
\hline & & & 3. advertisement \\
\hline & & & 4. invitation for senior MUAs. \\
\hline & \multirow{6}{*}{$\begin{array}{l}\text { opening the } \\
\text { registration for the } \\
\text { participants }\end{array}$} & \multirow{6}{*}{2} & 25 participants for each category. \\
\hline & & & Then, 50 participants for each category. \\
\hline & & & Next, 75 participants for each category. \\
\hline & & & After that, 100 participants for each category. \\
\hline & & & Totally, 300 participants. \\
\hline & & & Add with photographers, guests, assisstants. \\
\hline practice & the event runs & 3 & $\begin{array}{l}\text { Teaching the beginners / participants. } \\
\text { make up seminar, workshop, contest, the catwalk } \\
\text { fashion show, and photography. }\end{array}$ \\
\hline evaluation & Evaluation & 3 & Evaluating the event and publishing the article. \\
\hline
\end{tabular}

The event guides three parts such as preparation, practice, and evaluation [10].

\subsection{First month}

At the first month, the meeting are only held without any result.

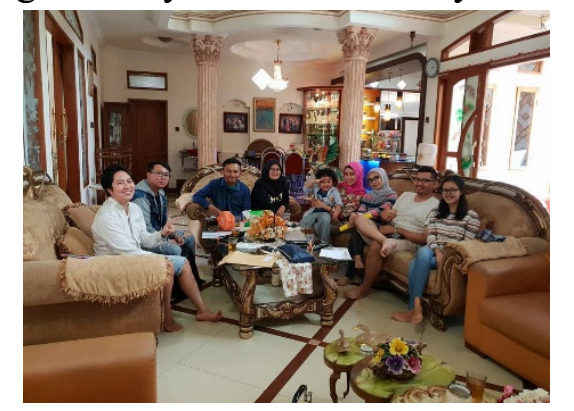

Figure 1. Monthly meeting

The Figure 1 shows about the meeting in the first month. They just discuss if whether or not they can make a big event that give benefit in makeuping people. Firstly, the researcher and her make up artists team have several discussion. Those are the community of MUA which have same jobs and monthly meeting. Secondly, they find an idea to make an event. They hopefully can produce the activity which gives the benefit for people, especially anyone who concern with make up. Thirdly, they arrange the composition of the commite. The researcher and the rest of the MUAs agree that they will be the committe. Because, they mostly join with several big events such as Putera Kebudayaan Indonesia, Puteri Kebudayaan Indonesia, Mister Grand Indonesia 
Jawa Barat 2018, Mister Grand Indonesia Jawa Barat 2019, Bandung The Wedding Concert Show 4.0 in Balai Pusdai, Man Hunt Indonesia 2018, they get link to held the event for a small scale. The researcher be a secretary of this event. She makes an event proposal, flyer, advertisement, invitation for senior make up artists. The event open the registration for only twenty five participants of make up class. After a small discusion, there are addition ideas, included the theme of event. The theme is ATMAISWARI. ATMA means the soul. ISWARI means the queen. ATMAISWARI means a the brideto-be should have a soul of the queen before being a truly queen in a day. Atmaiswari is also the goal of the make up artists to raise up the inner beauty of the bride.

\subsection{Second month}

At the second month, they contact several vendors to fix the due date and the place. The committee try to be serious in dealing with the event. A vendor agrees to support for the location. The committee go to several places to check the location. For example, they go to some buildings, ballrooms, hotels, villas that usually used for wedding celebration. Poorly, those places do not gather a lot of participants.

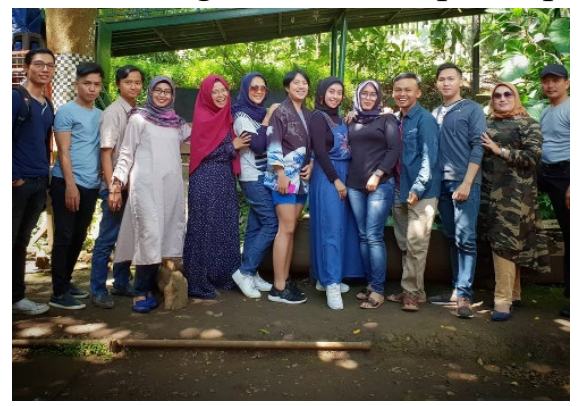

Figure 2. Checking some locations and keeping contacts with vendors

Then, after several discussion, they choose Istana Plaza. It is held at Atrium Istana Plaza Bandung, in Pasir Kaliki Street no. 121-123. The due date is March 8th, 2019. They choose Istana Plaza because the management agree with their criteria. The Istana Plaza has large space to deal with many participants. After the place, date, participants, and vendors are fixed, the commitee go to the location. They check the area for lightening, stage, the guests' cairs, entry door for the participants, registration, workshop place, make up place, fitting room, etc.

After the place is fixed, the commitee try to fix the concept. In the beginning, the commitee agree to open the registration for twenty five persons. The participants hopefully can join with make up class, since the commitee are being the MUAs. However, they realize that the makeup classes are spreaded in many occassions. Thus, they try to find out the special activities which differ their event. Then, the MUAs have collaboration with designers. The designer can not be independent. They need the models to show their dresses. Then, the concept move to the fashion show that relate to the MUAs, designers, and models. The point of scoring is based on total look.

Surprisingly, the participants are getting more and more. Based on the first planning, the fashion show just allows twenty five MUAs, twenty five designers, and twenty five models. However, the participants are overload. Thus, the committee revise the rule. 
They add the capacity of the participants. They open registration for fifty MUAs, fifty designers, and fifty models. Then, the registration is full. However, there are still many MUAs and designers who want to join the even. They do fully payment to make sure that they can be the participants. Thus, the commitee up the participants to seventy five for each category. The registration is going to burst. The commitee give the addition for the registration to one hundred for those three categories. It becomes full in days. It can not be denied that the commitee nervous to face the day. They feel anxious because it is their first project that cover around 300 participants. The commitee worries about the human resources who handle the event and the capacity of the location can not cover the additional participants. Although people still want to register, it is closed.

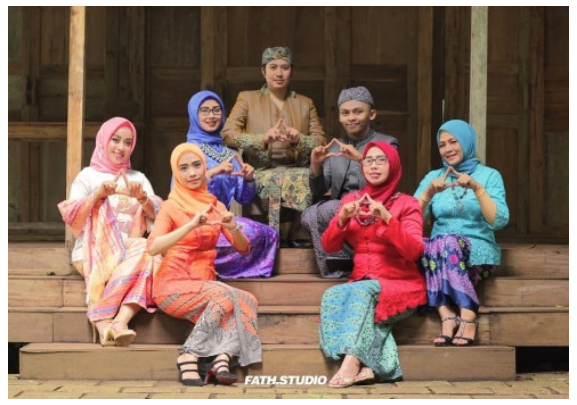

Figure 3. Online Advertisement

In the Figure 3 above, There are commitee for the event. They are seven Make Up Artists. They make video shooting which is published in instagram and youtube to promote the event. The symbol in their fingers show about the logo of ATMAISWARI. The logo and the advertisements blow up the idea of multiliteracy in multicontext and multiculture, especially for traditional and modern bridal [5].

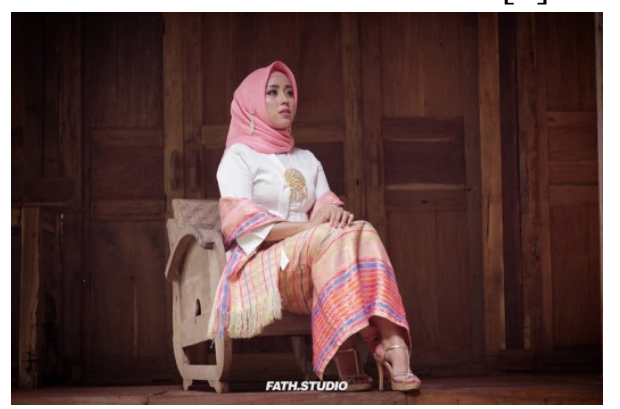

Figure 4. The researcher as one of the committee in ATMAISWARI

After the date, the participants and the location are fixed, the commitee blow up the promotions. The promotions increase the vendors. The vendors want to support the events. Radio, magazine, photograph, cosmetics, eyelash as several of many vendors that work hand in hand with the commitee. It is supported by Grab, Inez Cosmetics, Star Glam Majalahnya Bandung, BIG (Bandung Info Gaya), The Clinic Beautylosophy, Sister Eye Lash, Fath Photography, Istana Plaza, Lippo Malls, B Radio 95.6 FM Bandung, PR 107.5 FM, Studio East, 88.1 FM Bandung, Lendra Management, Alice Salendra, etc. 
The photographer community also join to support the event without any payment. They want to collaborate because it is a big event. They believe that the event is the first big event that gather MUA, designer, model, and the photographer.



Figure 5. Flyer and other advertisements are spread out

The photographer community from Bandung and other city join to the event. Talk about the people in the location, there are not only 300 participants, but also with assisstant to handle the make up. The professional photographers also bring their teams. The commitee can predict how crowded the situation in the due date. They also invite the senior MUAs such as Mba Ambar SIP, Ivan Belva, etc. There are also live music and dance. All of them are collaboration with vendor. This collaboration can be categorized as Contextual Teaching and Learning in the real life situation by learning community [7].

\subsection{The third month}

In the third month, the event is held. It is a big event with five activities: make up seminar, workshop, contest, the catwalk fashion show, and photography. It is explained briefly below.

\subsection{Make up seminar}

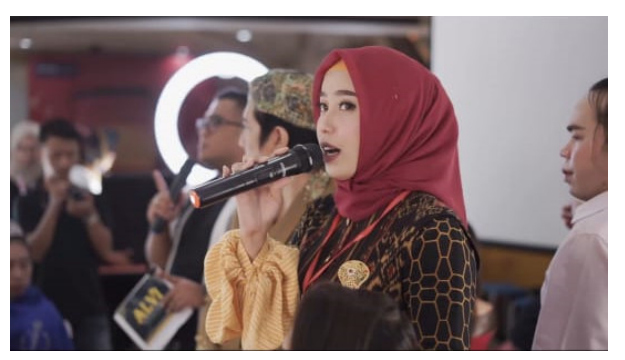

Figure 6. Presenter of Make Up Seminar

In make up seminar, there are three presenters. One of the presenter is the researcher. The theme for the make up class is bridal. The researcher as the presenter motivates the participants to see the opportunity in the bridal, make up, and design [8]. The preparation is started by finding out the model for the make up presentation. The second, find out the gown. Luckily, the bridal gown and accessoris is supported by a sponsor. The sponsor is Alice Salendra which is one of the famous designers in Indonesia. The hair do is supported by Baby Oniel. The nail art and Henna art is covered by Syifaul. The photogapher is Wastu Aji. The most important things are the 
equipments, the material to be presented, and also the skill of the presenters. The explanation on presentation supports the multiliteration learning model helps. The participants are being motivated to get higher level thinking skill and to apply in workshop[6].

\subsection{Workshop}

In the day, all of the participants already accompany by their models. All of them bring their equipment. Three presenters incleded the reseacher come foward. They also ask their models to take a seat in the stage. Then, they do the make up demonstation while the parcitipants also do the same activity. The training can be called as workshop to lead the parcicipants practice the make up [9]. This shows that workshop can be applied as kinds of multiliteracy. Multiliteracy in workshop makes the participants to be understand about the material explained by the presenters [2].

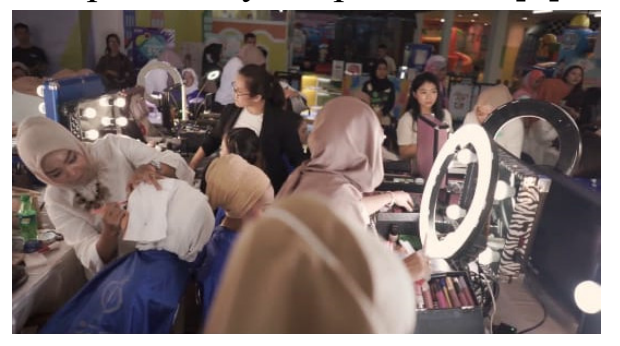

Figure 7. Workshop

\subsection{Contest}

The contests covers three categories: MUA, designer, and model. Every category provides six winners: the champion, the second champion, third winner, 1st runner up, 2nd runner up, 3rd runner up. The contest triggers the participants to do meaningful learning by doing workshop and contest[3].

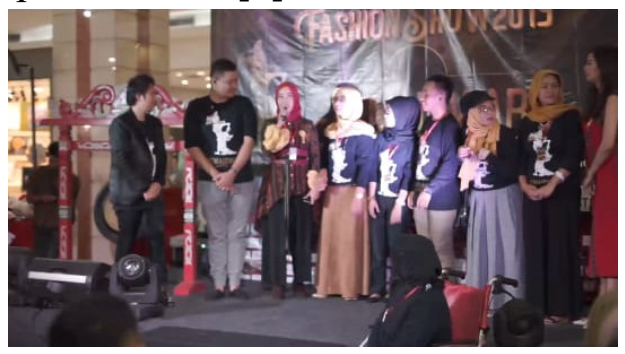

Figure 8. Contest

\subsection{The catwalk fashion show}

The catwalk fashion show also covers three categories: MUA, designer, and model. Every model who come foward to the stage is being a representative for her MUA and designer. The catwalk fashion show provides six winners to be spread out: the champion, the second champion, third winner, 1st runner up, 2nd runner up, 3rd runner up. 


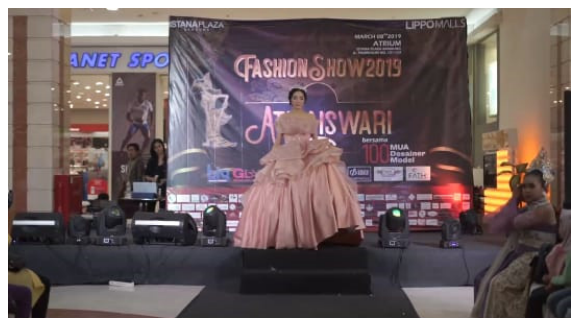

Figure 9. Catwalk

\subsection{Photography}

The photographers need objects to show their skills. It is the the strongest reason of many photogaphers come and take Figures. The radio and television are also their to show their participation in publishing the news. The photographers and media partners also get the certificate from ATMAISWARI.



Figure 10. Photography before make up

Based on the Figure 10, the photographers take the Figure since the model in bare make up. The also take photoghaph about the situation.

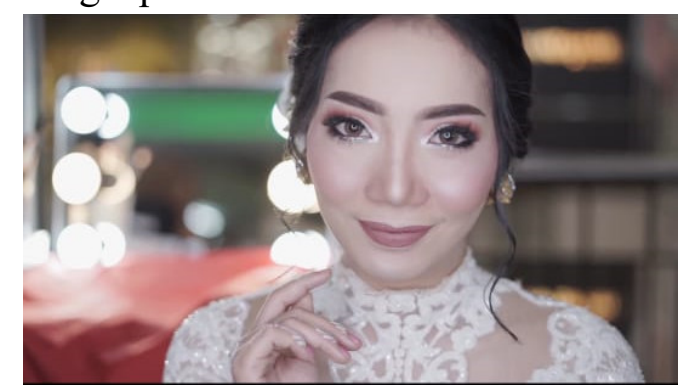

Figure 11. Photography after make up

The Figure 11 above shows the result of makeup. All of the photographies show that the participants have skill and knowledge [11]. From the explanation above, it can be concluded that ATMAISWARI take the concept of multiliteracy.

\section{Acknowledgment}

Sakti, Yugafiati, Karyono, and Maeliah thank to the God who help the researchers. Sakti and Yugafiati also thanks to family, relatives, and all of the lecturers who guide and support them to finish the paper. 


\section{References}

[1] Dafit, F. (2017). The Effect of Teahing Multiliteracy Model in Reading Skill of Elementary Students. Jurnal Inovasi Pendidikan dan Pembelajaran Sekolah Dasar. E-ISSN 2579-3403. Volume 1, nomor 1, Juli 2017. 87-100.

[2] Susilo, S.V., \& Garnisya, G. R. (2018). Penerapan Model Multiliterasi Untuk Meningkatkan Kemampuan Membaca Siswa Sekolah Dasar. Jurnal Cakrawala Pendas Vol.4 No. 2. Edisi Juli 2018. P-ISSN: 2442-7470. E-ISSN: 2579-4442

[3] Saputra, L. (2018). Pengaruh Model Pembelajaran Multiliterasi dan Kemampuan Berorganisasi terhadap Kemampuan Analisis Kimia Peserta Didik (Eksperimen Pada Peserta Didik SMA Negeri di Kecamatan Cilodong Kota Depok). Alfarisi:Jurnal Pendidikan MIPA Vol. 1, No. 1, April 2018, pp. 66-80. p-ISSN 2615-7756. E-ISSN: 2615-7748

[4] Sari, E.S., Suryaman, M., Lesyarini, B. (2013). Model Multiriterasi dalam Perkuliahan Pendidikan Bahasa dan Sastra Indonesia. LITERA, volume 12, nomor 2, october 2013. Pp 246-255.

[5] Nopilda, L.\& Kristiawan, M. (2018). Gerakan Literasi Sekolah Berbasis Pembelajaran Multiliterasi Sebuah Paradigma Pendidikan Abad Ke-21. JMKSP (Jurnal Manajemen, Kepemimpinan, dan Supervisi Pendidikan)Volume 3, No. 2. July-December 2018. Pp 216-231.

[6] Ginanjar A.Y. \& Widayanti, W. (2018). Penerapan Model Pembelajaran Multiliterasi Untuk Meningkatkan Kemampuan Literasi Matematis Siswa di SD/MI. Primary: Jurnal Keilmuan dan Kependidikan Dasar. P-ISSN: 20861362, e-ISSN: 2623-2685. Vol 10, no 2 (Juli-Desember) 2018

[7] Marlina, Pipin T.P., \& Suciati. (2011). Model Contextual Teaching and Learning (CTL) pada Perkuliahan Dasar Rias (Tata Kecantikan Wajah dan Rambut) Untuk Meningkatkan Kreatifitas Mahasiswa. Jurnal Penelitian Pendidikan. Vol. 12. No. 1. April 2011. Pp11-21.

[8] Windayani, N. R., \& Ihsani, A. N. N. (2014). Peningkatan Hasil Belajar Pada Rias Wajah Sehari-hari Melalui Multimedia Pembelajaran Interaktif di SMK N 1 Tegal. JBBHE 3 (1) (2014) Journal of Beauty and Beauty Health Education. ISSN 2252-7087. http://journal.unnes.ac.id/sju/index.php/bbhe

[9] Habibah, L. F. \& Nurlaela, L. Pemanfaatan Video Tutorial Rias Wajah Karakter Untuk Meningkatkan Kemampuan Merias Wajah Bagi Siswa Tata Kecantikan Rambut SMK Negeri 1 Sooko. e-Journal Volume 07 Nomor 1 tahun 2018, edisi Yudisium Periode Februari, hal 92-100.

[10] Apriliani, D. A. (2016). Kemampuan Tutor Dalam Memanfaatkan Media Pembelajaran Program Pelatihan Tata Rias di SKB Gunungkidul. Yogyakarta: Program Studi Pendidikan Luar Sekolah Jurusan Pendidikan Luar Sekolah Fakultas Ilmu Pendidikan Universitas Negeri Yogyakarta. Unpublished.

[11] Millah, H., \& Kustianti, N. (2017). Pelatihan Penataan Rambut Modifikasi Teknik Kepang Pada Siswa Kelas XI Kecantikan Rambut Di SMKN 2 Boyolangu. eJournal volume 06 Nomer 01 Tahun 2017. Edisi Yudisium Periode Februari, pp 51-58.UNESA: Unpublished. 